\title{
204 流れ方向強制振動食い違い配置二円柱まわりの渦流れ
}

The Vortex Flow Around a Pair of In-Line Forced Oscillating Staggered Arranged Circular Cylinder

$\begin{array}{llll}\text { 正 } & \text { 横井 嘉文 (防衛大) } & \text { 水野 } & \text { 紗聡 (防街大) } \\ \text { 河野 } & \text { 健（防衛大） } & \text { 西山 } & \text { 貴幸 (防衛大) } \\ \text { 大上 } & \text { 晃一郎 (防衛大) } & \text { 栗田 } & \text { 大樹 (防街大) }\end{array}$

Yoshifumi YOKOI, National Defense Academy of Japan, 1-10-20 Hashirimizu, Yokosuka 239-8686 Satoshi MIZUNO, National Defense Academy of Japan, 1-10-20 Hashirimizu, Yokosuka 239-8686 Ken KAWANO, National Defense Academy of Japan, 1-10-20 Hashirimizu, Yokosuka 239-8686 Takayuki NISHIYAMA, National Defense Academy of Japan, 1-10-20 Hashirimizu, Yokosuka 239-8686 Kouichiro OOUE, National Defense Academy of Japan, 1-10-20 Hashirimizu, Yokosuka 239-8686 Daiki KURITA, National Defense Academy of Japan, 1-10-20 Hashirimizu, Yokosuka 239-8686 Key Words : Vortex, Interference flow, Lock-in, Staggered Arrangement, Two Cylinders

\section{1. 精 豆}

流れの中に置かれた構造物は椱数の柱状物体より栱成さ れていることが多く，数多く萻皘されている単独の場合の知 見がそのまま䔔応できるかは保証の限りではない. 複数權造 物の最も単純な組み合わせ例として、,本の円柱を直列ある いは並列に配異して二円柱まわりの流れ特性や流れの様子 を調查した例は多く見受けられるが，その間の配置角度にお ける二円柱まわりの相互干涉流れについて調査された例は あまり無いのが現状のようである.まして非定常な流れ場に さらされた例はほとんど見受けられていない

本報では，配骨角度が $45^{\circ}$ の食い䢖い配罚二円柱を流れ 方向に強制的に振動させ周期的な相対流速の変勤がある非 定常流れ中の二円柱からの渦放出特性を既報 (1)で行った实 験範囲を桩大して調查した結果について報告する。

\section{2. 实悇菱畐および方法}

实験装而は既報 (1) で用いた回流水棈装覆と振勤装置と 可視化装贯および映像粑録装贯を用いた，回流水槽の測定 部の長さは $2 \mathrm{~m}$ ，幅は $0.8 \mathrm{~m}$ で水深は $0.4 \mathrm{~m}$ であり，測定部 の中央部付近の主流速 $0.4 \mathrm{~m} / \mathrm{s}$ に対する乱れの度合いは士 $1.5 \%$ 程度であった. 振動装贯は水槽測定部上に設けられて いて，振動装置に連接したスライドプレートに供試円柱が 取り付けられる。振期装圆の小型モ一タで回転円盤を回転 させ，スコッチヨーク機椎を用いて直線通動に変換させ円 柱を流れ方向に正弦的に振動させる. 振動パラメータの変 化は，回転円盤上の回転半径および回転円盤の回転数をそ れぞれ変化させることにより得られる. 可視化装骨およひ 映像記録装贯は，ビデオカメラ，ビデオレコーダ，眏像モ 二タ，500W ハロゲンライト（2 台）などから權成されてい る. 供試円柱は外径 $16 \mathrm{~mm}$ ，内径 $14 \mathrm{~mm}$ ，長さ $600 \mathrm{~mm}$ のア ルミニウム製で表面から互いに独立したトレーサ漫出孔が 2 か所 $\pm 60^{\circ}$ の角度で般けられている. 円柱は振功装量の スライドプレートに取付けられ，水面下 $140 \mathrm{~mm}$ の位显で トレーサ（ローダミン B）が浸出される.ふおたつの円柱は 便宜上、上流側にある円柱を第 1 円柱，下流側にある円柱 を第 2 円柱と呼んだ.

实験は既報 (1) と同様な方法と手順で行った. ふたつの 円柱の配是角度 $\alpha$ を $45^{\circ}$ に設定し, 距離比 $L / d$ を $1.5,2.5$, 5.5 にそれぞれ設定した後，振動パラメータの振的振幅比 $2 a / d(=0.25,0.5,0.75,1.0)$ および振功数比 $f / f_{K}(=0 \sim 5.5)$ を 変化させて，流れの様子を可視化钼測した。
流れ方向に振洏する単独円柱からの渦放出は，交互渦放 出 (A)，同時渦放出（S）に大別され，その二つの状態が 入れ替わって出現したり（A+S)，渦放出方向が振り子のよ うに変化する場合（P）が钼測されている. (2) 食い廷い四 置振動二円柱の场合にも振動単独円柱の場合と同様な分類 ができるが，マッシュルーム顔面形状の渦を形成する场合 （m）と相方の円柱に邪度をされ片側のみしか渦放出が無 い场合 (o) を加えてフローパターンの分類を行った。渦放 出のスケッチを図 1 に示す. 食い運い配早された振勤二円柱 における個々の円柱からの渦放出によって形成されるフロー

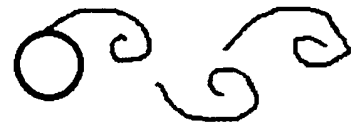

A (Alternate)

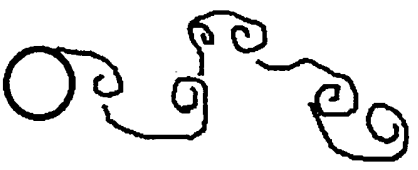

AP (Alternate + Pendulum)
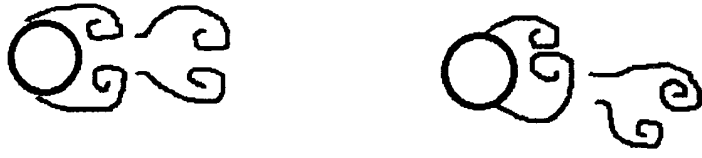

S (Simultaneous)

SP (Simultaneous + Pendulum)
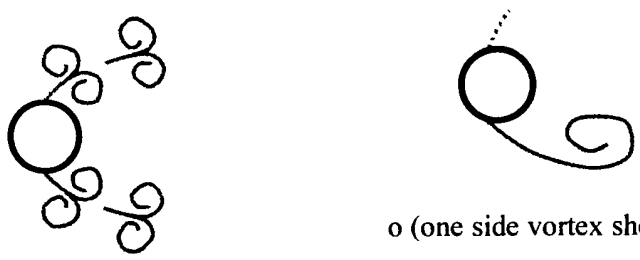

o (one side vortex shedding)

m (mushroom type vortex shedding)

Fig. 1 Sketches of the vortex shedding situation from an oscillating cylinder

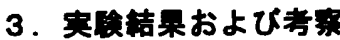


パターンの分布およびロックインの発生状況を横刺に振功数 比，維轴に振幅比をとって距離比ごとに図示する. 図 2 は距 離比 $L / d=1.5$ の堨合, 図 3 は距離比 $L / d=2.5$ の埸合, 図 4 は距 雄比 $L / d=5.5$ の場合をそれぞれ示している. 各図において，振 幅比ごとにデータは 5 段に打点されている. 图中にて，中段 は比较のための単独円柱のフローパターンが貶されている. 下段は第 1 円柱のフローパターン，最下段は第 1 円柱のロッ クインが記されている. 上段は第 2 円柱のフローパターン， 最上段は第 2 円柱のロックインが記されている. 図中の祀号 はフローパターンでは渦の放出形態により大別されていて， O印系統（图中赤色）は交互洞放出 (A)，口印系統（図中㮏 色）は同時渦放出（S）， $\Delta$ 印系統（図中緑色）は交互と同時 が混在する渦放出（A+S）を示している.ここで，凡例中の 文字祀号「P」は渦放出方向が振り子のように变化する埥合，

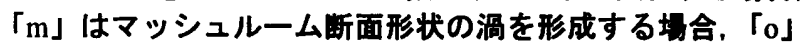
は相方の円柱に邪筧をされ片側のみしか渦放出が無い场合を 示している. ロックインの発生状況では○旫（図中赤色筀注 し）は交互渦放出型のロックイン (Alternate vortex shedding type Lock-in = A Lock-in)，口印（図中色色港し）は同時渦 放出型のロックイン (Simultaneous vortex shedding type Lock-in $=\mathrm{S}$ Lock-in）を示している. なお，図中にてデータの打点が 無い所は渦として琶識出来ずにカウントが出来ない状態であ ることを意味する．距離比によらず振幅比が大きくなると誢 測できる渦の振勤数笵囲が狭くなる傾向にあることが胃てと れる. 距雄比が大きく円柱同士が雄れている塂合（ $L / d=5.5 ）$ においても第 1 円柱のフローパターンと第 2 円柱のフローパ ターンはおおよそ同じであるが，単独円柱の場合と县なるフ ローパターンが出現している. 距離比を小さく円柱同士を近 つけると，相互干渉の効果が表れ出してくる. 特に振耐祘波 数比 $f / f_{K}$ が $1 \sim 3$ の笵囲にて，両円柱のフローパターンは顆藉 な这いが見られている.

二円柱の相互干涉が強く現れる状態においても，ロックイ ンすることが見てとれる. 高周波数側の振勒数では第 1 円柱 と第 2 円柱ともロックインする振勒数の笵囲は同じであが 低周波数側では第 1 円柱と第 2 円柱では異なっている. 振都 振幅を変化させるとロックインする渻囲はあまり变化はない か， 同時渦放出型のロックイン ( $f_{V K} / f=1 / 1$ のロックイン) の 筑囲が広がるなどのロックインの内容に亲化が胃られた．距 離比が $L / d=1.5$ の時（図 2)，第 1 円柱で渦放出がある時は口 ックインが生じている. また，第 1 月柱が交互渦放出型の口 ックイン (A Lock-in) を起こしている時に, 第 2 円柱が同時 渦放出型のロックイン（S Lock-in）が生じているという現象 が起きている.この現象は距離比 $L / d=1.5$ の埥合にしか現れな かった. 距離比が $L / d=2.5$ の時（図 3）, 振轩数比 $f / f_{K}=0.6$ 以上 の筑囲では第 1 円柱と第 2 円柱ともロックインする倾向が見 られる. また振幅比 $2 a / d=0.25$ の時, 振的周波数比 $f / f_{K}=1.8 \sim 3$ の筂囲では交互渦放出型のロックインであったが，振幅比 $2 a / d=0.5$ の時では同じ振的周波数の䈌囲では同時渦放出型の ロックインであった. 距離比が $L / d=5.5$ の時（図 4)，交互渦 放出型のロックインと同時渦放出型のロックインの出現振峌 数带は第 1 円柱と第 2 円柱においてほとんど变わりはなかっ た. なお，振幅比が小さいとロックインし始めるまではほと んど觧止時の渦放出周波数と同じであった.

\section{4. 結 豆}

配是角度を $45^{\circ}$ とした食い遗い眍是の二円柱において， 3 種類の距離比について流れ方向に振峌させた時の流れの 様子や渦放出特性を調查した結果，以下の事柄を得た。

（1）フローパターンの分布は単独円柱の场合と比较し て異なることや, 距離比によりおのおのの円柱においてつ
ローパターンの分布が異なること。

（2）二円柱後流が相互干涉している条件下で振勤させ てもロックインがそれぞれの円柱で生じること。

\section{奉考文孰}

（1）横井・他 4 名，機陆确，No. 12-40 (2012)， 385.

（2）横井・平尾，機論 B， 74-746 (2008)， 2099.

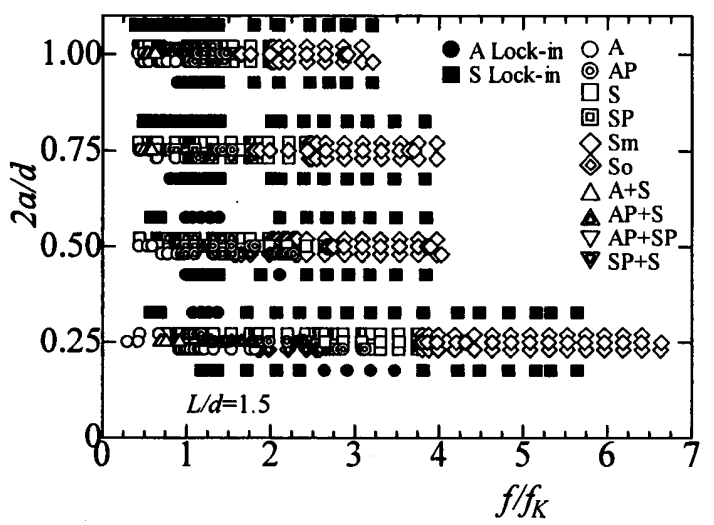

Fig. 2 Flow pattern and lock-in distributions in the case of $L / d=1.5$

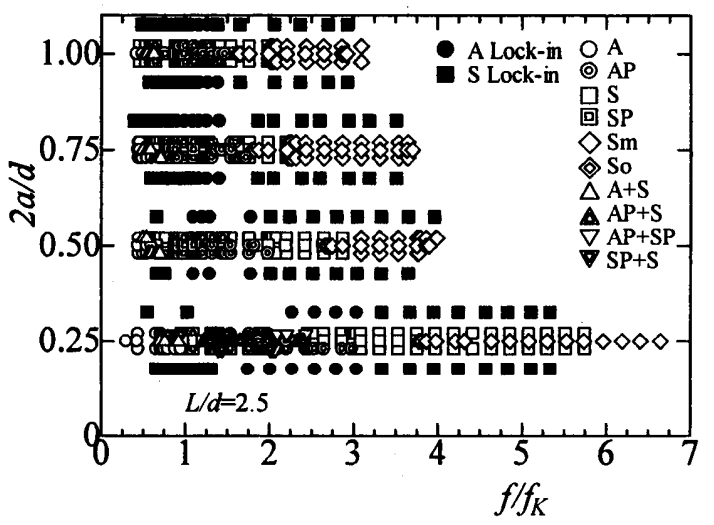

Fig. 3 Flow pattern and lock-in distributions in the case of $L / d=2.5$

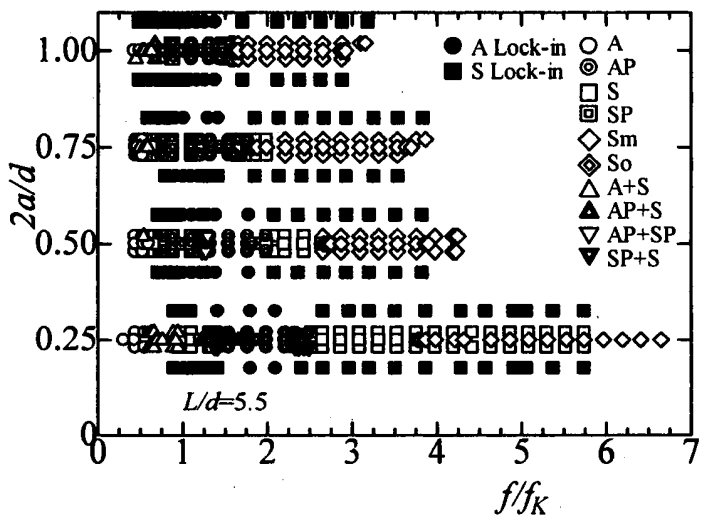

Fig. 4 Flow pattern and lock-in distributions in the case of $L / d=5.5$ 